\title{
The Contemporary Landscape of Arabic Translation: A Postcolonial Perspective
}

\author{
Halla A. Shureteh \\ Department of English Language and Literature, the Hashemite University, Zarqa, Jordan
}

\begin{abstract}
Arabic translation assumed an unrivaled identity and dignity from the mid 8th century up until the Mongol's conquest of Baghdad in 1258. This period is termed as the Golden Era of Arabic Translation ${ }^{1}$ on the grounds of the superb achievements of Medieval Arabic translators and their Abbasid patrons. It is widely celebrated in the context of Arabic literary and intellectual tradition, and attracts more interest and notice than any other stage in the history of Arabic translation. One of the most prominent problems of contemporary Arabic translation is that present-day Arabic translators are viewed and assessed in contrastive relation to their venerable Medieval counterparts. Given the successive political upheavals that overwhelmed Arabic history following the fall of Baghdad in the eleventh century, and ending up with the violence escalating nowadays throughout several Arab countries, contemporary Arabic translation ought to be viewed and assessed in light of the historical facts and present-day challenges that might have impeded its anticipated development. In this essay, I intend to outline and map from various perspectives the landscape of contemporary Arabic translation primarily in terms of the achievements and challenges that face Arabic translators nowadays.
\end{abstract}

Index Terms - translation studies, Arabic translation, Medieval Arabic translators, state of translation, postcolonial translation

\section{Current Questionable Evaluations of Arabic Translation}

There is a current a wide-spread sentiment as Clark (2000) puts it that "the Arab world contrasts a glorious mythical past with a frustratingly bitter present" (p. 23). ${ }^{2}$ In most of the evaluations of the contemporary scene of Arabic translation, one observation seems to assert itself repeatedly, that is: there seems to be a sharp contrast between an organized institutionalized past, and a feeble chaotic state stigmatizing the theory and practising of contemporary Arabic translation. In other words, Arabic translation is often studied and presented through a distorting prism which takes into account only the glorious role of Medieval Arabic translators in transmitting Greek knowledge to Medieval Europe on a large scale.

Lichtblau (1991) notes that "in the 1950s the notion that the world could be changed for the better and that literature should contribute to this effort struck many [writers] as both persuasive and exciting." Lichtblau explains that such writers who were taken by this notion had a strong passion for Jean Paul Sartre and "his thesis that the writer's commitment was to his own times and to the society in which he lived, that words were actions, and through writing a man might influence history" (Lichtblau, 1991, p. 1). In the Arab world, this feeling about the commitment and responsibility of writers and intellectuals struck many twentieth-century Arab writers as well when many Arab countries were either still in the grip of colonisation or in the aftermath of cultural colonisation. In his lecture, "Translation and Modern Arab Renaissance" (1992) Jabra Ibrahim Jabra, a twentieth-century Arab fiction writer, essayist and translator calls Arab translators and writers to acknowledge the significant role Arabic translation can play nowadays to promote the modern Arab renaissance and "bring the Arab nation back to its original notable position within the broad context of civilisations" (Jabra, 1992, p. 57). Jabra places Arabic translation within a purely cultural context viewing it only as a means of restoration or reconstruction of the glorious past. He calls upon Arab writers and translators to acknowledge that translation can play a significant role to boost the development of Arab nations in modern times, in the same way the superb translation movement had done during the days of Al-Ma'mun and Harun Al-Rashid" ${ }^{3}$ (p. 58).

Said Faiq's study "Arabic Translation: a Glorious Past but a Meek Present" (2000) is another obvious case in point. Faiq depicts the contemporary Arabic translation scene as being in sharp contrast with the prestige, respect, and significance translation enjoyed in the Medieval Islamic world. "In the modern Arab world," he says, translation is neglected. It "receives neither the same attention, nor the encouragement as its counterparts in Europe and America, nor does it enjoy the prestige bestowed upon its Medieval ancestor" (Faiq, 2000, p. 83).

\footnotetext{
${ }^{1}$ The Golden Era of Arabic translation actually "started during the reign of the Umayyads (661-750) and reached its zenith under the Abbasids (7501280), particularly, during the time of [the Caliph] Al-Ma'mun (813-833)" (Baker, 2001, p. 318). For further reading see (Gutas, 1998, pp. 75-104).

${ }^{2}$ See also (Faiq, 2000, pp. 83-98), and (Shunnaq, 1996).

${ }^{3}$ Al-Rashid was the fifth Abbasid caliph (786-809). His reign was marked by scientific, cultural prosperity. He established the famous library and translation center Bayt al-Hikma (House of Wisdom) which flourished during al-Ma'mun's reign (813 - 833), another Abbasid caliph and patron of Arabic translation.
} 
It is quite difficult and also unfair to assess the contemporary state of Arabic translation through the perspective of the past only. By so doing such assessments which always depict Arabic translation as chaotic and underdeveloped when compared with the superb achievements of Medieval Arabic translators, lay big pressure and responsibility on present-day Arabic translators to change the presumed state of underdevelopment in the Arab world. According to Lichtblau (1991), "we live in an age of smug skepticism about the power of literature as well as history" (p. 1), and presumably other fields of knowledge including translation. In the Arab world of today, the escalating political and social unrest sweeping over several countries of the Middle East is overwhelmingly frustrating. Amid the bloody rebellions and conflicts raging in these countries today, no one can hope that literature or translation will have a superb transforming power to change the big tides of events.

Moreover, the discipline of Translation Studies worldwide is recognized today as a relatively new field that is still in the making. Baker (2001) believes that its "potential is as yet unrealized" (p. xiii) even in Europe and the United States. According to Keeley (1980), the state of translation and translators in the United States is fairly grim, "though not quite as grim as they [translators] once were" (p. 14) because translation has been for a long time regarded as a subsection of Comparative Literature. Even today Translation Studies are housed within departments of Cultural Studies or Comparative Literature. Bassnett (1991) writes.

In 1978, in a brief Appendix to the collected papers of the 1976 Louvain Colloquium on Literature and Translation, Andre Lefevere proposed that the name Translation Studies should be adopted for the discipline that concerns itself with the 'problems raised by the production and description of translations.' (Bassnett, 1991, p. 1)

As a matter of fact, Anthony Pym (1999) maintains that translation is academically homeless all over the world and "the people doing Translation Studies are scattered all over kinds of Academic institutions." Pym laments the issue that up until today, there is still "no firm institutional home" for Translation Studies with no exception to any translation tradition (p. 2). However, evaluations of contemporary Arabic translation often single out Arabic translation as chaotic and feeble with no institutional home in academia. Such distorting views of Arabic translation do nothing but enhance the wide- spread misconception which uses the prism of the past to view the current situation of Arabic translation. Faiq (2000) claims that Arabic translation enjoys no "independent identity, but rather it is assigned a secondary status within language departments" (p. 83).

In his introduction to Rethinking Translation: Discourse, Subjectivity Ideology (1992), Lawrence Venuti, a prominent scholar of contemporary translation theories, describes the status of translation in the Anglo-American world as being "an invisible practice" that is "rarely acknowledged" (Venuti, 1992, p. 1). Venuti maintains that the discrimination against translators in the Anglo-American world is very obvious, since the translator's work is never highly appreciated, for instance, "many standard translation contracts at trade and university publishers assign the translator below-subsistence fees "per thousand words"” (p. 2). The fact that translators are mostly, paid by the word, as though translation is a pure mechanical work far from creativity and authenticity, shows that "the translator's labor" is in "eclipse." In spite of the considerably hard work, translators have a "shadowy existence" in their societies (p. 1). Venuti is a strong authority on the subject of the invisibility of translators in the Anglo-American tradition. Throughout his influential book, The Translators' Invisibility (1995), Venuti points out that in the Anglo-American culture, translators are only successful when they make themselves "invisible" and "transparent" so that only the source text and the original author are seen through their arduous task. At the end of his book, Venuti calls the invisible translators "to action" to enforce "a change in contemporary thinking about translation" (Venuti, 1995, p. 312). Venuti and other contemporary translation theorists talk about a widespread dilemma encountering all translators not restrictively of a particular culture. His observations on the low status of translators and translation in the Anglo-American world are clearly in conflict with some contemporary evaluations of Arabic translation which depict Arabic translation as underdeveloped compared to the theoretical and practical activities of translation in other cultures. Such evaluations restrict translators' low social standing and marginality exclusively to Arabic translators. However, Anthony Pym (1996) confirms that with no exception to any culture "everywhere I found Venuti's resistant translators 'banished to the fringes' of not just Anglo-American culture but of whatever culture they were involved with” (p. 2).

\section{CATASTROPHic Chapters IN THE History OF ARABiC Translation}

There is a considerable body of research in the field of Translation Studies that highlights the vast instrumental contribution of Medieval Arabic translators to Western learning and thought as the greatest transmissions of knowledge in history. However, the historical conditions which gave rise to such significant periods of heightened translation activities in the Medieval Islamic and Arab world have changed considerably over the centuries. The evaluations of the contemporary scene of Arabic translation which look at the present through the eyes of the superb past only are obliged to look into historical facts also before formulating any judgment. Despite the fact that today we find more than fifty Muslim countries divided politically, linguistically and culturally, contemporary evaluations of Arabic translation treat these different fifty countries as one cultural whole. In such evaluations, it has to be noted that the Islamic empire began to split politically, linguistically and culturally as a result of successive invasions and offensives as early as the eleventh century. Al-Sayyad et al. (1971) maintains that during and following those invasions, the literary and cultural heritage suffered considerably. The caliphs, who acted as generous patrons sponsoring intellectuals, translators, and institutions of learning, had to give more time and finance now to wars and efforts of protection in the face of these invasions rather 
than to sponsoring careers of writing and translation. Also, the new rulers who took power in the Islamic world were foreigners who knew no Arabic. As a consequence, the heightened activities of authorship and translation took a gradual slope. Gradually, Arab translators could no longer enjoy the patronage, encouragement and attention as used to happen through their major Abbasid patrons who would sustain them as they proceeded with their translations (AlSayyad et al., 1971, p. 188).

\section{A. The First Invasions}

The worst of these invasions, which resulted in the most intense loss of the cultural, historical, scientific, and literary heritage, took place when Baghdad fell to the Mongols. This is often referred to as the most culturally-disastrous incident in the history of Islam and the Arabs. Baghdad was the prosperous center of the Islamic world and remained so for over five-hundred years until it was destroyed by Hulegu and the Mongols in 1258. The destruction of Baghdad and the Abbasid Caliphate was on a large scale and left a profound impact on the respected medieval Arabic learning and translation. Morgan (2007) states, "the battle with the Mongols is pitiful [...] the caliph is strangled [...] the structures of the city are pillaged, battered, and burned, many reduced to rubble" (pp. 145-146). The Mongols destroyed the Abbasids' prosperous learning centers and libraries including the House of Wisdom, the unrivaled medieval translation and research institute which had international fame to scientists, philosophers, translators, and linguists of the Muslim and non-Muslim world. Saunders (1965) points out that "the loss to culture in the fall of Baghdad alone is incalculable" (p. 195). The extent of knowledge lost during the devastation of Baghdad and its libraries was massive. Books were either burned or dumped into the Tigris River in large quantities. Lane (2006) maintains,

The accusation of book burning and in particular the charge of willfully destroying the literary heritage of Baghdad have long blackened the reputation of Hulegu Khan [...] Unfortunately, nothing remains today of the center of learning [...] in later accounts of the destruction of Baghdad, reference is made to the burning of books and to the Tigris running black with the ink from the desecrated tomes. (p. 88)

The destruction of Baghdad, the center of learning, is considered the most catastrophic chapter in Islamic cultural history as it put an end to more than five hundred years of cultural achievements and breakthroughs. Morgan (2007) writes, "the destruction of the city is so complete that, though some will try to rebuild it in coming centuries, it will never regain any prominence in world affairs until its oil-funded rebirth in the $20^{\text {th }}$ century" (pp. 145-146). Unfortunately, most present-day evaluations of the contemporary scene of Arabic translation highlight the medieval golden achievements of Arabic translators during the days of Al Ma'mun and Al-Rashid, the devoted Abbasid patrons of translation without bringing to light in the same context the grave consequences of that catastrophic interruption in the development of Arabic translation and learning at the hands of that invasion.

\section{B. Modern European Invasions}

Another force that brought major change and interruption in the development of Islamic and Arabic culture was the penetration of European colonialism in all Muslim and Arab states during the nineteenth and twentieth centuries. Over a span of two hundred years or so, the arrival of European colonialism forced a completely different political, social and cultural pattern over the Arab and Islamic world. Nasr (1999) maintains that during and after the colonisation of the Muslim and Arab world "the territorial division of Muslim lands [...] went hand in hand with national confusion and the fracturing of the future national society" (p. 559). The European colonisation left profound impacts on the development of Arab societies and their cultures. The idea of the guiding unity that prevailed in the vast Islamic empire and gave rise to periods of prosperity in authorship, learning, and translation became more and more unworkable. In fact, the arrival of colonialism is a key factor in explaining the present-day political, ethnic, religious, linguistic, and cultural divergences in the states that emerged by the end of the colonial era. European colonisation changed the course of everything and everyplace in the Arab and Muslim world giving rise to politically, culturally and linguistically divided populations and nations. Also, the economics, ideology, and leadership of the states formed during and after the colonial era became completely detached from each other.

The appreciation and high esteem bestowed upon specific fields of knowledge and sciences especially translation in the Medieval Islamic world were affected by the detrimental impact of cultural colonisation and the gradual deterioration it extended to the present. Edward Said (1994) argues that, even though imperialism was over by the end of World War II, its consequences are continuous and had enduring impact on the cultures of the colonised countries, "the era of high or classical imperialism [...] formally ended with the dismantling of the great colonial structures after World War Two, [but] has in one way or another continued to exert considerable cultural influence in the present" (p. 6). Even years after gaining their independence from France, the Arab countries of Algeria, Tunisia, and Morocco are still toiling to bring back standard Arabic as their official language. Fanon (1963) believes that the cultural colonisation of a nation is more threatening and destructive than all forms of colonialism. "Colonialism is not satisfied merely with holding people in its grip and emptying the native's brain of all form and content, by a kind of perverted logic, it turns to the past of the oppressed people, and distorts, disfigures and destroys it" (Fanon, 1963, p. 210). The Arab countries of Algeria, Tunisia, and Morocco remained in the grip of French colonisation for almost a century. Tarwater (2005) believes, "despite almost 50 years of independence, they have been unable to reposition themselves to be stable, selfsufficient nations. Instead, Algeria, Morocco, and Tunisia waver behind, struggling to define the gaps in their culture that resulted from the colonialist era" (Tarwater, 2005). European colonialism remade the whole Arab world. de 
Larramendi (2008) argues that after gaining their independence from the French colonisation, the Arab Maghrebi countries of Morocco, Tunisia, Algeria, Mauritania, Libya have exerted extended efforts over many years to establish a united Maghrebi union of these countries on the grounds of "historic, religious, cultural and economic reasons." However, the "political differences, distrust over security issues [...] have brought the Maghrebi unification process to a standstill. Obstructions to unification have undermined the region's ability to negotiate as a bloc, resulting in economic isolation and political marginalisation" (p. 179). Dirks (1992) believes that colonialism is "itself a cultural project of control," culture suffers "in certain important ways, culture was what colonialism was all about" (p. 3). European colonialism never believed in the power of any native civilisation or culture of the Arab world. If these cultures were not abolished or broken into pieces, their old ways, their old ideas, and their old laws were Europeanised. Through the enduring cultural colonisation, "cultural forms in newly classified ways "traditional" societies were restructured and transformed" (Dirks, 1992, p. 3). Perhaps most important nowadays are the rebellions and conflicts escalating in Tunisia, Libya, Yemen, Iraq, Egypt and Syria. These conflicts are starting to be seen by political analysts and peoples of these countries not as part of an historical turn of events for these nations or a new start of a bright future as thought at the outbreak of these conflicts. In an article titled, "a Century of Violence: What World War I Did to the Middle East," Zand (2014) maintains that the ongoing conflicts are actually not a beginning but "the most recent chapter in an almost uninterrupted regional conflict that began 100 years ago and has never really come to an end."

\section{More CURRENT UnREASONABLE JUdGMENTS}

Unfortunately, most of the modern-day evaluations that often talk of bitterness overwhelming the contemporary state of Arabic translation and culture leave out the catastrophic effects of cultural colonisation on the development of nations from their calculations and therefore should not be passed as reasonable judgments. It is necessary to rethink these unfair generalised views. Before casting any judgment on the current state of Arabic translation, critics need to throw light on any controlling historical changes, old and new, and their effects on the Arabic culture over time. Equally important to looking closely and rightly into the past of Arabic translation, critics need to map the reality of present-day landscape of Arabic translation also closely and rightly taking into account the contemporary valuable achievements and the big challenges that control the development of Arabic translation nowadays.

In the often taken-for-granted evaluations of the contemporary scene of Arabic translation, another indicator of the poor status of Arabic translation appears to be the percentages of Arabic translations published annually nowadays. Arabic translation percentages are more often than not judged low and poor when compared with the number of translations published in other languages and cultures, or even worse when compared to the always higher ratio of books during the time of the caliph, Al-Ma'mun. Al-Jaber (2014) points out that the eminent British Orientalist and Historian of Islamic arts, Thomas Arnold, describes the achievements of Medieval Arab scientists and translators as being "at the height of their greatness, lighting up as the moon shines, and dissipating the depths of darkness, which wrapped Europe in the Middle Ages." Jaber's reaction to the special praise Arnold gives to the Golden Islamic Era is as such: Arnold's "words are like tales from Arabian Nights" that he likes to listen to whenever he wants "to escape the reality" of a bitter present "to a world of romantic fantasy, dreams and visions." One of the indicators of the deterioration of Arabic advancement in arts and sciences used in present-day evaluations is the poor percentage of books translated in the Arab world nowadays compared with the books translated into Hebrew for example. Al-Jaber writes "Israel translates 15,000 books into Hebrew, once described as a dead language, every year compared with the Arab world which does not translate more than 330 books into Arabic every year" (Al-Jaber, 2004).

In a similar argument, Faiq (2000) comments on the number of books that had been translated into Arabic between the years (1960-1970) as being "meager" when compared with the number of books translated during the time of AlMa'mun. "The 2840 books ${ }^{4}$ translated over a decade for a total population exceeding 130 million is meager indeed, and indicates the poor esteem in which translation is held $[\ldots]$ This rate of translation is a far cry from what Al-Ma'mun managed as a ruler of one nation [...] 114 philosophy books, 123 mathematics books, and 149 medical books" (p. 88). Faiq continues to view and present contemporary Arabic translation through the lenses of the past framing it in sharp contrast with the status of Arabic translation at the days of Al-Ma'mun:

If Al-Ma'mun managed to create a culture of translation that led to the translation of hundreds of books when acquiring these books and producing the translations were laborious and time-consuming activities, one might wonder why sixteen modern Arab nations managed only 2840 translations between them despite all the modern technologies at their disposal. (Faiq, 2000, pp. 88-89)

However, while discussing the insufficiency or rather serious shortage of contemporary practical Arabic translation activities, the author himself conceded in the same article that "there is very little documentation in terms of training and books translated" (Faiq, 2000, p. 88).

In his study of the activities of Palestinian translators from the renaissance to the end of the twentieth century, AlKhatib (1995) uses Al-Khouri's statistical study of the Arabic translations up until 1988. Al-Khatib maintains that the numbers appearing in Al-Khouri's study are actually not quite accurate. For instance, Al-Khouri does not take into

\footnotetext{
${ }^{4}$ Faiq quoted this number from a statistical study of 1988, by Shehada Al-Khouri, the former General Director of the Arab Organisation for Culture, Education, and Sciences. See (Al-Khouri, 1988)
} 
account all the books translated by Palestinian translators between the years (1970-1980). As a matter of fact, Al-Khouri only lists those books that were published officially by the former Palestinian Liberation Organisation (Al-Khatib, 1995, pp. 108-109).

Such comparisons might seem convincing especially if one takes into consideration the vast modern technological tools and facilities now available and accessible to Arab translators and were not available to their counterpart ancestors during the Golden Era of Arabic translation. In point of fact, such studies suggest that generally speaking, the Arabic language culture is devoid of translations nowadays. As noted earlier in this paper, before formulating any evaluations, such studies have to take into consideration the historical and cultural transformations in the Islamic and Arab world beginning with the end of the Islamic Golden Era at the hands of the Mongols in the eleventh century and ending with the nineteenth and twentieth centuries' political and cultural subjugation of the Arab and Islamic world by the European empires of Britain, France, Italy, Holland, and Russia. The Islamic empire once stretching "from present-day Pakistan to Spain" (Baker, 2001, p. 316) with one shared ideology and leadership does no longer exist. It was split up, broken into pieces and its historical achievements were dispersed in many countries. The most significant problem in these studies is that they tend to disregard historical changes and treat fifty-two linguistically and culturally diverse Arab and Islamic countries as one cultural whole. After the termination of colonisation, the unified Arab world fell apart, and twenty-two Arab nation states rose to existence. It can't be denied that in the past, the shared existing political system that successfully ruled over the far-stretching parts of Islamic empire from Baghdad was behind the flourishing of all fields of knowledge especially Arabic translation. As early as the eleventh century, the colonial powers that subjugated the Islamic and Arab world had destabilised and wreaked the unity that surely nourished and sustained its prosperity in the Middle Ages. Of the devastating effects of colonialism, which can be traced up to this day are the political borders imposed on Arab and Muslim states in the twentieth century after the division of the Islamic and Arab world amongst the colonial powers. Today these borders became roots and fruits of conflicts amongst Arab and or Muslim states generating long-term political and ethnic tensions such as the Iraqi-Iranian war which lasted over ten years and the Gulf War of 1990 ensued because of Iraq's claim to Kuwaiti territories. Nasr (1999) points out that the"ethnic and territorial definitions became the boundaries for national identity formation; they grew roots and developed as a secular and dominant form of political identity in lieu of memories of united Islamic world in history" (p. 558). If one takes the enduring impact of colonisation including the political divisions and cultural divergences it brought to the present into account, it becomes quite fair not to expect a balance in the ratio of literary production or translations in these linguistically and culturally diverse countries to those produced in the united Islamic world as an entirety in the Medieval past.

\section{CONTEMPORARY ACHIEVEMENTS}

As noted earlier in this paper, most of the assessments of the contemporary landscape Arabic translation tend too readily to make harsh judgments through the lenses of the Medieval past in spite of all the radical changes that overwhelmed and transformed the course of everything in Arab world. It is regrettable how various persistent accomplishments of present-day Arab translators are often left out of consideration and disregarded because the glorious past acts as the only perspective critics use to view and talk about present-day Arabic translation and culture. This obviously restricted view does not allow critics of the contemporary scene of Arabic translation to value many contemporary bright achievements of Arabic translators which range from individual successful translations to the contributions of journals and big non-profit projects of translation including the Franklin Project for the Translation of Arabic, one of the largest English-Arabic translation projects of the twentieth century ${ }^{5}$, PROTA and the recent Kalima.

The big Project of Translation from Arabic, PROTA, is one of those contributing projects whose potential was overlooked and not at all realized in modern-day assessments. Allen (1994) confirms that "in a space of a single decade," PROTA "has initiated and supervised the publication of a body of translated works, and more recently of studies, that constitute a significant addition for [...] the repertoire of sources in English for the Arab World, and in particular, its literature" (p. 168). PROTA started "to take shape towards the end of the 1970s, as an anthology project for Columbia University Press" under the direction of Salma Khadra al-Jayyusi, the Palestinian literary critic and poet. PROTA's main objective was "the dissemination of Arabic culture and literature abroad." Through the efforts of a vast number of translators "in the US, Britain and the Arab world," it managed successfully the publication of two vast volumes of Arabic poetry and narratives (Allen, 1994, p. 166). PROTA's first successful publication was followed by another series of flourishing translations of Arabic books, anthologies and individual works principally not for commercial use. ${ }^{6}$

\footnotetext{
${ }^{5}$ See (Al-Khatib, 1995, p. 38).

6 Among anthologies, The Literature of Modern Arabia (Salma Khadra Jayyusi, ed. London, 1988; Austin, 1990) and an Anthology of Modern Palestinian Literature (Salma Khadra Jayyusi, ed. New York, 1992). An Anthology of modern Arabic drama. Smaller anthologies contain collections of poems by the Tunisian Abu al-Qasim Al-Shabbi (Tunis, 1987) and Syrian Mohammad al-Maghut (Washington, 1991) and also short stories and novellas by Ghassan Kanafani (Austin, 1990) and Liyanah Badr (New York, 1993). The Project has also published individual novels by Emily Habiby (New York, 1982), Sahar Khalifah (London, 1986), Yusuf al-Qa-id (London 1986), Hamza Bogary (Austin, 1991), Ibrahim Nasrallah (New York, 1993), and Zayd Dammaji (New York, 1994). For detailed information on the titles of books translated and published by PROTA, see (Allen, 1994, pp. 165-168).
} 
Another well-designed project of Arabic translation which should be brought to light in present-day evaluations of Arabic translation is the non-profit translation project of Kalima initiated by the Abu Dhabi Authority for Culture and Heritage. Every year, the Kalima project for Arabic translation publishes one-hundred translations of high quality works of literature, arts and sciences from several languages into Arabic. Kalima's principal goals are to sponsor the translation, publication and distribution of quality works from all genres and languages into Arabic. The project also supports and promotes the Arabic book production on the international stage. Moreover, Kalima helps improve the sociology of Arabic translation by reinforcing translation as a dignified profession through encouraging translators to be part of their promising and prospering endeavor. In addition to publishing translations in significant numbers, Kalima offers a variety of useful programs and services to translators, interpreters and theoreticians, including international book fairs and the annual Abu Dhabi International Conference for Translation which aims at examining and developing the current state of translation around the Arab world. The outcome of such translation initiatives deserves to be much commended in modern-day evaluations of Arabic translation because of their big potential and merits. In literature, a considerable body of translations from and into Arabic made distinctive contributions to the catalogues of World Literature. Moreover, the increasing numbers of translations into and from Arabic opened up newer areas of scholarly research and generated the academic study of Arabic literature in translation in and outside the Arabic milieu. This in turn has contributed to the development of newer academic programs of Arabic cultural studies and Arabic translation research at several universities around the world.

In his study of the Palestinian translation movement, Husam Al-Khatib (1995) documents the achievements of Palestinian translators from the renaissance up until the end of the twentieth century. According to Al-Khatib, "translation flourished very early as a result of the widespread existence of the foreign schools and missionaries in the Holy Land as early as the second half of the nineteenth century" (p. 15). There were many Russian missionary schools in Palestine towards the end of the nineteenth century. "The Palestinian-Russian Association was established in 1882 along with a series of Russian schools." Many Arab students who were granted scholarships to study in Russia became committed distinguished translators, such as Khalil Baidas who in 1908 initiated "Al-Nafae's Magazine," one of the most important Arabic publications dedicated to translation at the beginning of the twentieth century (pp. 16-17). According to Al-Khatib, Palestinian translators contributed to Arabic translation more than any others, essentially, as a result of the political situation that involuntarily forced many of them to live in diaspora. They have translated from a wide variety of subjects in English, French, Greek, Russian, Turkish, and Hebrew among many other languages (AlKhatib, 1995, pp. 47-61).

Translation in the Arab world is not perhaps widely recognized as a firmly- established discipline in its own right. However, the field of Arabic translation is in the moving and has witnessed significant developments in theory as well as in practising. As far as the theoretical development of Arabic translation is concerned, a substantial number of books, dissertations, and theses get published constantly. Moreover, in addition to the large number of journals that publish Arabic translations regularly, there are now academic journals entirely devoted to theoretical studies of translation in general and to Arabic translation in particular including the Journal of Translation Studies, Turjuman [The Translator] published by The King Fahd School of Translation, and the publication of the Jordanian Translators' Association Studies in Translation. Moreover, taken by the rapid growth and expansion of the discipline of Translation Studies in the world, there are now more than any other time in the history of Arabic translation, more researchers, theoreticians, publishers, editors, practioners of translation and interpreting and students working in the field of Arabic translation in every country throughout the Arab world. Furthermore, well-organized conferences and forums on Arabic translation are held throughout the year and on a regular basis by Academies and schools of translation and interpreting to help promote the development of professional translators and researchers through panel discussions, expert presentations, training workshops, and scholarly papers. Moreover, the academicisation of the training of translators and interpreters has flourished with the development of the discipline of Translation Studies around the world. There is now a reasonable number of schools, academies or university-level institutions that offer academic training and/or welldeveloped undergraduate as well as graduate degree programs in translation and interpreting including the recent Translation and Interpreting Institute, at Hamad bin Khalifa University, the Graduate program in English-Arabic translation at Yarmouk University in Jordan and its counterpart at the University of Jordan. The King Fahd School of Translation in Tangier, Morocco is also a very well-known translator academy throughout the world. According to Faiq (2000), it "has endeavored to create a translation culture within Morocco in particular, and the rest of the Arab world in general" (p. 89). Surprisingly enough, such successful academies are either overlooked or often seen by some as exceptions from the chronic, chaotic and underdeveloped contemporary state of Arabic translation.

There is yet another bright spot that is to be commended in the contemporary efforts to endorse and promote Arabic translation and translators. Translation awards and grants of different kinds are given each year to literary and nonliterary translators into and from Arabic around the world including (1) the King Abdullah bin Abdulaziz's International Award for Translation, (2) the International Award of Translation given by the Kuwait Foundation for the Advancement of Sciences, (3) the Translation Award given by Sheikh Zayed Book Award, (4) and the annual Banipal Prize for Arabic Literary Translation. Most of the awarding organisations are governmental and initiated these grants and awards on the basis of their belief that translators deserve to be given credit for their labors and art. 
As far as Arabic literary translation is concerned, achievements in the field include the publication of Banipal: a Magazine of Modern Arab Literature introduced in 1998, to come three times a year as Clark (2000) maintains for the sake of bringing "contemporary Arab literature into mainstream" mostly through English translations. In addition to publishing the magazine of modern Arabic literature in English translations, Banipal also supports the publication of two books of poetry or fiction a year, publishing a wide range of authors from all parts of the Arab world and its diaspora in a variety of genres and styles. "Its marketing strategy is to get across to the British [and international] literary public and the indications are that it is achieving some degree of success" (Clark, 2000, p. 14). Roger Allen, a specialist in Arabic literature and Arabic language pedagogy in the United States comments on the excellent availability of Arabic literature in English translation saying:

In 1993 I taught an NEH summer seminar for high school teachers on the Arabic novel in translation. As I went through the listing of translated novels that are available in 1990s and also made a choice from translations of other genres as back-up material, I became newly aware of the wealth of materials that we now have available [...] there are now sufficient published novels and anthologies of poetry, drama and short stories to devote entire courses or at least significant segments of them to individual genres and themes. (Allen, 1994, p. 165)

In his article "Arabic Translation A Glorious Past but a meek Present" (2000), Faiq maintains that the main reason behind the low status of Arabic translation in the Arab world "is the fact that it is restricted to the university sphere where it is then further hindered by the low priority attached to it" (p. 91). Faiq means by "the low priority attached" to Arabic translation that in the Arab world, translation is still housed within language and literature departments. Translation Studies as a discipline is still not widely academically institutionalized even at distinguished European and American universities. Unfortunately, to this day, Translation Studies are mostly housed within departments of Linguistics, Comparative Literature or departments of Cultural Studies. In the whole North America, for instance, there are only few fully-fledged ph.D programs in Translation Studies. To cope with the rapid growth in the field of translation studies, some Arab universities, such as the Yarmouk University in Jordan nowadays have departments of translation established to offer a complete program of study in translation at the B.A and the M.A. levels. The department of translation at Yarmouk is planning to offer a ph. D program in Arabic-English translation in the near future.

Translation in the Arab world has developed a great deal as a result of the collective or collaborative efforts of individual translators, publishers as well governmental and nongovernmental translation houses and associations as Professor Al-Shunnaq, an expert of Arabic translation studies maintains:

From the beginning of the $19^{\text {th }}$ century up to the mid $20^{\text {th }}$ century, the translation movement in the Arab world was represented by efforts exerted by individuals as well as publishing houses and distributors. However, in the 1950s, official organizations were established by some Arab countries to sponsor translation affairs. Ministries of Culture, Information, Education, Higher Education, universities and academies of Arabic language, among others have shouldered the responsibilities of translating, publishing and distributing for almost the last five decades. The activities of private publishing houses and individuals have gone on side by side with these governmental bodies. (Shunnaq, 1996, p. 12)

The Arab world witnessed a general state of cultural renaissance and awakening over the years (1970s-1980s) (AlKhatib, 1995, p. 48), which in turn brought the materialisation of an organised translation tradition as a result of the appearance of Arab associations for translators in the mid 1980s (p. 49). Generally speaking, Arab translation associations are non-profit bodies, which work on, among many other objectives, establishing internal links between Arab translators in one country as well as establishing links with other translators in Arab and international organisations of translators. The Syrian Translators' Society, The Jordanian Translators' Association, The Iraqi Translators' Association, King Fahd School of Translation and the Arab Translators Federation (A.T.F.) are the most known examples of such organisations in the Arab world.

\section{PResent-Day Challenges}

The development of Translation Studies as a discipline is a success story of the 1980s only. (Bassnett and Lefevere, 1990, p. ix). In the Arab world, the subject has developed in terms of theory and practising and is clearly to continue developing well into the twenty-first century. The Arab world is constantly living in a time of rapid and radical political, social and economical changes that surely and inevitably affect the nature and development of academic disciplines and fields of knowledge. The development in Arabic translation studies nowadays owes part of its success to the prestigious past of Arabic translation as well as to the developments in the field of Translation Studies as a whole. Translation in the Arab world is deeply steeped in the history of Arabs and Islam. There is no doubt that the relative prestige and power of Arabic translation have fluctuated over time following many historical changes. One big reason for the low ranking of contemporary Arabic translation is the restricted comparisons of Arabic translation to its glorious Medieval counterpart. Apparently, there are many more individual and collective efforts still needed to develop an awareness of translation as a discipline and respected profession. Also, nowadays, Arabic translators work hard, but their biggest challenge and fear would be when they work in isolation with no one documenting their achievements. Systematic 
documentation is required and can help change the course of contemporary Arabic translation and literature ${ }^{7}$ Most needed in this respect perhaps is a project similar to the International Directory and Guide for Translation and Translators compiled by Stephan Congrat-Butlar. This directory can be a regular compilation of whatever information needed about the discipline and profession of Arabic translation for students, researchers and everybody interested in the field of Arabic translation. This may include information about practioners, translators and interpreters, educationalists and their achievements, as well as the work of institutional enterprises and projects. It may include also a bibliography of all publications in the field of Arabic translation to be used and consulted by researchers and students. Information about organisations, societies, and institutes, prizes, awards, fellowships, translation workshops, seminars, conferences and programs leading to undergraduate as well as graduate degrees or certificate may also be added. Such compilation is really indispensable and can paint a bright picture about the contemporary activities and achievements of Arabic translation.

There is no doubt that Arabic translation is developing in quite new ways. However, this paper is a call for more systematic projects that may brighten up the fairly grim picture mistakenly drawn about Arabic translation. The endeavors to develop Arabic translation may have to include also regular attempts to publish professional serious conversations and interviews with contemporary accomplished literary and nonliterary Arab translators and educationalists of Arabic translation including Mohammed Shahin, Issa Boullata, Abdil Wahid Lu'lu'a, and Salih Ilmani to reveal the contemporary achievements of Arabic translators, bring them to international contexts and more importantly to enable Arabic translation to assume a visible identity.

Another challenge that faces Arabic translators nowadays is expressed by Edward Said in his article, "the Embargoed Literature." Said comments on the non-popularity of Arabic literature in the West saying that "the unavailability of Arabic Literature in translation is no longer an excuse" (Said, 1995, p. 99). Said connects the semi-anonymity of Arabic literature or what he calls "the cultural abyss that exists between the Arabs and the West" to various reasons that range from "political and military polarization" to "the responsibility of Arab writers themselves as well as their publishing houses, ministries of culture, embassies in Western capitals who have done hardly nothing to promote their works" ( $\mathrm{p}$. 102). What needs to be done is finding ways of circulating the translated works into broader contexts and also making the translations more functional in the target languages.

A further challenge for Arab translators and Arab translation organisations nowadays seems to be the problem that "the complete hegemony of English and French in the Arab world has hindered contact with other languages and cultures" (Faiq, 2000, p. 92). ${ }^{8}$ Arabic translation has to open up to other cultures, ideologies and languages. This is easy to accomplish particularly if we take into consideration that quite relevant to the bitter profiling of contemporary Arabic translation is the fact that in the Arab world, translation has always been perceived essentially as a cultural activity or a means of restoration, revival and reconstruction of the glorious past. In other words, translation is often seen not as a linguistic creative task, art or science but as a means of cultural exchange more specifically for the sake of development, growth and reformation. ${ }^{9}$ This might put great pressure and limitations on the nature of works that get translated and published into and from Arabic.

\section{FinAL ThOughts}

The landscape of contemporary Arabic translation is tremendously broad. To cover it in just few pages is a huge responsibility. Unfortunately, there has been no comprehensive adequate study of the scene of the contemporary translation tradition in the Arab world. In the present essay, I have attempted to offer an overview of the most prominent features, challenges of the state of contemporary Arabic translation, and to highlight the most prominent profile and framing, which dominate the discussions of the state of Arabic translation. The pattern of the theoretical and practical development of Arabic translation has not always been consistent and the relative power of Arabic translation has fluctuated throughout Arabic history following periods of colonisation which inevitably affected and interrupted its course of development. In this paper, I have attempted to show that the present state of Arabic translation is not as it is often portrayed: not too all positive or inspiring. Contemporary studies and assessments of Arabic translation tend too often unjustly and too readily to contrast the superb past of Arabic translation with the developing present. Typically, that has resulted in undermining and underestimating the contemporary achievements of translators. Many of these assessments which look at translation as a cultural transfer or a form of reconstruction are perceived only through the prism of the past away from present-day challenges. This is not to say that the past of Arabic translation is irrelevant to studying the present. It has to be employed in really motivating new ways for Arabic translators. The best policy to try to change the grim picture would be to stop lamenting the glorious past and to establish carefully reasoned evaluations of the contemporary achievements in light of the present-day challenges and historical facts. Perhaps in this way only we can establish respectability for contemporary Arabic translation.

\footnotetext{
${ }^{7}$ Critics maintain that Jabra Ibrahim Jabra's translation of Sir James Frazer "The Golden Bough" from English into Arabic was behind the appearance of what is called the Tammuzi Movement in contemporary Arabic poetry. See (Abu-Shamsieh, 1987, p. 40; pp. 52-55).

8 "By the early part of the $20^{\text {th }}$ century, most of the Arab world was under occupation, with the British in Egypt, Palestine, Sudan and Iraq, the French in North Africa and Syria [and Lebanon]" (Baker, 2001, p. 324).

${ }^{9}$ Mohammed Ali's vast translation project in Egypt at the beginning of the nineteenth century, which lasted about twenty years, was carried out for the sake of reformation, see (Baker, 2001, pp. 322-324) and also (Al-Shayyal, 1951, pp. 1-10)
} 


\section{REFERENCES}

[1] Abu- Shamsieh, I. M. (1987). Jabra Ibrahim Jabra's Fiction: A Study of his Themes and Techniques. Ph.D dissertation, Bloomington: Indiana University.

[2] Al-Jaber, K. (2014). Our Present Past and Future. The Peninsula. http://thepeninsulaqatar.com/qatar-perspective/khalid-aljaber/267672/our-present-past-and-future (accessed 28/02/2014).

[3] Al-Khatib, H. (1995). Harakat at-Tarjama al Filastiniah mina an-Nahdha hatta Awakhir al-Qarn al-Eshreen [The Palestinian Translation Movement from the Renaissance to the End of the Twentieth Century]. Beirut: Al-Mo'asasah al-Arabiyya lidDirasat wa an-Nashr.

[4] Al-Khouri, S. (1988). At-Tarjama Qadiman wa Hadithan [Translation: Past and Present]. Sousa: Dar Al- Ma'arif.

[5] Allen, R. (1994). PROTA: The Project for the Translation of Arabic. Middle East Studies Association Bulletin 28.2, 165-168.

[6] Al-Sayyad, M. et al. (1971). Al-Mujtama' al-Arabi wa al qadiyya al Filastiniah [The Arab Society and the Palestinian Cause]. Beirut: Dar- al Nahdha Press.

[7] Al-Shayyal, J. (1951). Tarikh at-Tarjama wa al-haraka al- Thaqafiya fi Asr Mohammad Ali [The History of Translation and the Cultural Movement in the Era of Mohammad Ali]. Cairo: Dar-al Fikr Al-Arabi.

[8] Baker, M. (ed.) (2001). Routledge Encyclopedia of Translation Studies. London: Routledge.

[9] Bassnett, S. \& A. Lefevere (eds.) (1990). Translation, History and Culture. London and New York: Pinter Publishers.

[10] Bassnett, S. (1991). Translation Studies. London: Routledge.

[11] Clark, P. (2000). Arabic Literature Unveiled: Challenges of Translation. Durham Middle East Papers No.63, 1-27. Durham: Center for Middle Eastern and Islamic Studies.

[12] Congrat-Butler, S. (ed.) (1979). Translation \& Translators: An International Directory and Guide. New York: R.R Boulker.

[13] de Larramendi, M. H. (2008). Intra Maghrebi Relations Unitary Myth and National Interests. In Y. H. Zoubir and H. Amirah (eds.), North Africa: Politics, Region, and the Limits of Transformation. New York: Routledge, 179-201.

[14] Dirks, N. B. (1992). Colonialism and Culture. Michigan: University of Michigan Press.

[15] Faiq, S. (2000). Arabic Translation: A Glorious Past but a Meek Present. In M. G. Rose (ed.), Translation Perspectives XI: Beyond the Western Tradition, Binghamton: State University of New York at Binghamton, 83-98.

[16] Fanon, F. (1963). The Wretched of the Earth. New York: Grove Press.

[17] Gutas, D. (1998). Greek Thought, Arabic Culture: The Graeco- Arabic Translation Movement in Baghdad and Early Abbasid Society ( 2 nd $-4^{\text {th }} / 8^{\text {th }}-10^{\text {th }}$ centuries). London: Routledge.

[18] Jabra, J. I. (1992). Mu'aayashat al-namirah: wa- awraaq ukhraa [Living with the Tigress and Other Papers]. Beirut: AlMo'asasah al-Arabiyya lid-Dirasat wa an-Nashr.

[19] Keeley, E. (1980). The State of Translation. In D. Weissbort (ed.), Modern Poetry in Translation No. 41-42. London: Modern Poetry in Translation Ltd, 7-18.

[20] Lane, G. (2006). Daily Life in the Mongol Empire. Westport: Greenwood Publishing Group.

[21] Lichtblau, M. I. (ed.) (1991). A Writer's Reality. New York: Syracuse University Press.

[22] Nasr, S.V.R. (1999). European Colonialism and the Emergence of Modern Muslim States. In J. L. Esposito (ed.), The Oxford History of Islam. Oxford: Oxford University Press, 549-599.

[23] Morgan, M. H. (2007). Lost History: The Enduring Legacy of Muslim Scientists, Thinkers, and Artists. New York: National Geographic Society.

[24] Pym, A. (1996). Venuti's Visibility. Target 8.2, 165-177. http://usuaris.tinet.cat/apym/on-line/translation/1996_Venuti.pdf (accessed 12/02/2014).

[25] Pym, A. (1999). Why Translation Studies Should Learn to be Homeless. In M. A. P. Martins (ed.), Tradução $e$ multidisciplinaridade. Rio de Janeiro: PUC/Lucerna, 35-51. http://usuaris.tinet.cat/apym/online/research_methods/1999_homeless.pdf (accessed 28/01/2014).

[26] Said, E. (1994). Culture and Imperialism. New York: Vintage

[27] Said, E. (1995). The Embargoed Literature. In A. Dingwaney \& C. Maier (eds.), Between Languages and Cultures: Translation and Cross Cultural Texts. Pittsburg: University of Pittsburg Press, 97-102.

[28] Saunders, J.J. (1965). History of Medieval Islam. London: Routledge.

[29] Zand, B. (2014). A Century of Violence: What World War I Did to the Middle East. Spiegel Online International. http://www.spiegel.de/international/world/world-war-i-led-to-a-century-of-violence-in-the-middle-east-a-946052.html (accessed 31/01/2014).

[30] Shunnaq, A. (1996). The Translation Movement in Jordan and the Role of the Jordanian Translators Association (JTA) Language International, 8.4, 10-13. Amsterdam: John Benjamins Publishing.

[31] Tarwater, A. (2005). French Colonization in the Maghreb: A Central Influence in Both Regions Today. $\mathrm{http} / / / \mathrm{msmeerson} . w e e b l y . c o m /$ uploads/1/0/6/0/10605783/french_colonization_in_the_maghreb.pdf (accessed 20/04/2014).

[32] Venuti, L. (ed.) (1992). Rethinking Translation: Discourse, Subjectivity Ideology. London: Routledge.

[33] Venuti, L. (1995). The Translator's Invisibility: A History of Translation. London: Routledge.

Halla A. Shureteh, Assistant Professor of Comparative Literature and Translation Studies, has a Ph. D. from State University of New York at Binghamton (USA), 2005. Currently she works at the department of English of the Hashemite University, Jordan. Her research interests include primarily contemporary Arabic translation, postcolonial studies, the philosophy of translation, literary translation, translator/interpreter training, translation quality assessment, and contemporary American women writers. She has published articles on translation studies and comparative literature with emphasis on contemporary translation and literary theories. 